\title{
REHABILITATING GALLIO AND HIS JUDGEMENT IN ACTS 18:14-15
}

\author{
Bruce Winter
}

\begin{abstract}
Summary
By first-century Graeco-Roman standards, a recent assessment of Gallio - a Roman senator, proconsul and consul of Rome - would have been seen as something of a damnatio that resulted in the dismissal of his achievements and the formal disfiguring of his name from the imperial inscription that bears it in Delphi. However, a re-examination of the evidence of ancient witnesses comes to a somewhat different conclusion about this important Roman senator. Such testimonies would confirm Luke's presentation of this legally competent proconsul who made a landmark judgement under Roman law on the status of the early Christian movement.
\end{abstract}

\section{Introduction}

It has been said of Gallio that he deserted his post as proconsul of Achaea before his tenure had expired because he was 'a fussy hypochondriac' - a conclusion said to be 'confirmed by Pliny [the Elder]'s report' ${ }^{1}$ His Achaean appointment has thereby been judged a 'failure'. ${ }^{2}$ Yet the Emperor Claudius, in an official letter to Delphi, commended Gallio for his diligence in providing a report for the resettling of that ancient cultic centre and owned him officially as "my friend and proconsul' of Achaea. ${ }^{3}$

When governors of provinces returned to Rome, charges could be laid against them and, if proven, they would suffer damnatio and their

1 J. Murphy-O'Connor, St Paul's Corinth: Texts and Archaeology (3rd ed; Collegeville: Liturgical, 2002): 168.

2 Murphy-O'Connor, St Paul's Corinth: 168.

3 See p. 295 for the inscription. 
names defaced from official inscriptions. ${ }^{4}$ The name of Gallio was preserved in the Delphi inscription.

After this older brother of Seneca the Younger left Corinth, he held the prestigious office of suffect consul of Rome. However, even the significance of that achievement, while acknowledged, is undermined: 'His [Gallio's] failure in Achaia forgotten, he was named Consul [of Rome] in AD 59.'5

There is a record of Gallio as Nero's official herald announcing the emperor's appearance in the theatre, but this role is described somewhat pejoratively in canine terms as that of a 'barker'. ${ }^{6}$ His reaction in the Senate in Rome, when he became terrified for his own safety following his younger brother's death in the purge of Nero, is used only to confirm further negative views of this man.

Even the assessment of Gallio by his distinguished brother, who was a leading philosopher and high-ranking official in Rome, has been rejected: 'The judgement [by his younger brother, Seneca the Younger] does more credit to the author's charity than to his intelligence.'7

In New Testament studies, Gallio seems to have suffered the same fate that can still happen in 'polite society', where damnatio can now be done simply by declaring '... but he has a nice wife'. Is it also the case that Gallio's one 'redeeming' feature is found in the official Delphi inscription of Claudius, which accidentally provided scholars with a reasonably secure date because the year of the reign of Claudius is declared; i.e., '12th year of tribunician power, acclaimed emperor for 26th time'? His only significance would be this incidental reference to him in the Delphi inscription because it provides a fairly fixed point for the chronology of early Christianity and the Pauline mission. ${ }^{8}$

While E. A. Judge has called him a 'meticulous' lawyer, ${ }^{9}$ if the most recent assessment of Gallio is correct, then it might colour our assessment of his legal competence in refusing to proceed with the case of the Jews versus Paul in Acts 18:14-15, and at the same time discredit his

4 See R. Syme, 'C. Vibius Maximus, Prefect of Egypt' Historia 6 (1957): 484.

5 Murphy-O'Connor, St Paul's Corinth: 168.

6 Murphy-O'Connor, St Paul's Corinth: 169.

7 Murphy-O'Connor, St Paul's Corinth: 169.

8 W. Dittenberger, ed., Sylloge inscriptionum graecarum (4 vols.; Leipzig, 1915-24), 2:801.

9 E. A. Judge, The Social Pattern of Christian Groups in the First Century (London: Tyndale, 1960): 69. 
ruling on the status of the early Christian movement in the eyes of Roman law.

The purpose of this contribution is to see whether Gallio should be rehabilitated by revisiting extant extra-biblical witnesses to this son of the famous philospher, Seneca the Elder.

By first-century Roman standards the categories of Gallio's rank as senator and his status in terms of the official offices he held would give an immediate profile of his persona and determine precisely who he was. For our study we will use rather the Pauline canon based on the Old Testament, and stated in 2 Corinthians 13:1, of assessing any damnatio by examining the testimony of extant ancient witnesses. Given what we can learn of this man, his education, health, character, and career, it will be concluded that Gallio deserves to be rehabilitated, and that important weight should be given to his legal opinion regarding the status of this early Christian movement, as a confirmation of his legal competence.

\section{The Man, Lucius Junius Gallio Annaeus}

Gallio's father was Annaeus Lucius Seneca (c.50 BC-c.AD 40), the famous Stoic philosopher known to us as Seneca the Elder. His wife, Helvia, bore three sons, the oldest being Gallio (BC), Seneca the Younger (c.4 BC-AD 65) and Mela, the youngest.

His younger brother, Seneca the Younger, who is better known because of his extensive extant corpus, was also a Stoic philosopher who himself had been rehabilitated after being exiled from Rome in the early part of principate of Claudius, through the machinations of the emperor's unchaste wife, Messallina. He returned and was subsequently appointed tutor to the twelve-year-old Nero, whose close confidant he remained when the aforementioned was appointed emperor three months before his seventeenth birthday. Seneca the Younger went on to become a leading politician during his Principate and was known as Nero's amicus principis.

\section{Educating Gallio}

Seneca the Elder, although born in Spain, resided in Rome from the mid 30s BC until $8 \mathrm{BC}$ when he returned to his homeland. He spent his time at the centre of the empire in the hope of becoming a senator, a 
dream to be realised only through his two sons, Gallio and Seneca the Younger. When the older two were seven and five years old, their father returned to Rome in order to supervise his sons' education, leaving his wife behind in Spain to manage his estates.

The father's ambition for his sons is revealed in his preface to Book Two of Controversiae where he contrasts 'the zeal with which he had encouraged his first two sons to become orators and senators' with his youngest son's desire to study philosophy. Both were taken by their father more than once to hear Scaurus declaim, which was all part of his close supervision of their education. We are indebted to Janet Fairweather in her important monograph on Seneca the Elder for the amount of detail she has collated concerning the education programme the young men's father had mapped out - and his somewhat adventurous nature in endorsing aspects of rhetorical training that were regarded as avant garde. Their training was to include not only philosophy, which he regarded as essential to their education, but also rhetoric, which would fit them a legal career in the Roman administration. ${ }^{10}$

\section{Gallio's career path}

Of Gallio's early Roman period we know that at some stage he was adopted by a leading senator, L. Junius Gallio, in what appears to have been a 'testamentary adoption'; that is, he became a beneficiary of his estate, and as a result he changed his name from Lucius Annaeus Novatus to that of Lucius Junius Gallio Annaeus, a rhetorician in Rome and a significant political figure. This choice for Junius Gallio was a significant one because we know how much Seneca the Elder endorsed his style of oratory and declamation. ${ }^{11}$

By AD 37, both sons had moved through the ranks and were made senators, which must have rejoiced their father's heart and spurred him on for the remaining two years of his life to write his two works Controversiae and Suasoriae. In them, he describes what he had stored up in his prodigious memory nearly half a century previously in Rome: the literary discussions and the works of Roman orators to whom he had listened all those years ago.

Gallio was made a senator in AD 37 and subsequently appointed to the proconsulship of Achaea in $\mathrm{AD} \mathrm{51/2} \mathrm{-} \mathrm{'a} \mathrm{promising} \mathrm{post} \mathrm{in} \mathrm{view} \mathrm{of}$

10 J. Fairweather, 'The History of Declamation', Seneca the Elder (Cambridge: Cambridge University, 1981): ch. 2.

11 Fairweather, Seneca the Elder: 277-9. 
Claudius' affection for Greece and the Greeks'. ${ }^{12}$ Following his service in that province he became a suffect consul in Rome, and later a herald of Nero. ${ }^{13}$ Seneca the Younger would write of Gallio to a friend that he 'conquered honours [in his career path] by industry'. ${ }^{14}$

\section{Claudius' 'friend' and Rome's Consul}

Had Gallio's own father lived, neither he nor his adopted father would have been disappointed when, in an official Delphic letter from the Emperor Claudius, Lucius Junius Gallio was given the official accolade 'my friend and proconsul' (ó pí Claudius' assessment of Gallio is reflected in the official letter he wrote to the people of Dephi.

Tiberius Claudius Caesar Augustus Germanicus, 12th year of tribunician power, acclaimed emperor for 26th time, father of the fatherland, sends greetings to [the Council of the Delphians, greetings]. For I have long been well-disposed to the city of Delphi but also its prosperity, and I have always observed the cult of the Pythian Apollo. Now since it is said to be destitute of citizens, as my friend and proconsul, L. Iunius Gallio recently reported to me, and desiring that it should regain its former splendour, I command you to invite well-born people also from other cities to come to Delphi as new inhabitants, and to accord them and their children all the privileges of the Delphians as being citizens on like and equal terms...For if some [strangers] had transferred [to these] parts [as citizens] - - - - - - - - -order that - - - - [nothing] of what is written therein [be] subject to dispute. ${ }^{15}$

Claudius planned to revive Delphi's fortunes. Suetonius in his work 'The Deified Claudius' referred to this reforming mindset of his. 'As regards sacred rites ... both at home and abroad he [Claudius] corrected various practices or reinstated those which had fallen into disuse, or else instituted new arrangements' and undertook this in his role of pontifex maximus. ${ }^{16}$ It had always been a small town of some one thousand inhabitants and, like Jerusalem, had long been dependent economically on its religious significance. The former city was now in

12 M. I. Griffin, Nero: the End of a Dynasty,(London: Batsford, 1984): 253 citing Suetonius, 'The Deified Claudius': 22. See below for citation.

13 Seneca, Dialogues: 12.7.

14 Seneca, Dialogues: 12.7.

15 The first four fragments of the letter were discovered in 1905 and three more fragments five years later, which were published in 1913, SIG 2.801. It was not until 1967 that two more were uncovered and published by A. Plassart, 'L'inscription de Delphes mentionnant le proconsul Gallion' REG 80 (1967): 372-78.

16 Suetonius, 'The Deified Claudius': 22. 
decline in spite of the fact that Augustus had restored the Amphictyony College that administered its revered sanctuary. ${ }^{17}$ It no longer attracted residents, visitors or devotees as it had once done.

Suetonius recorded that Claudius 'devoted no less attention to Greek studies ... And when commending Achaea to the Senate, he would note that this province was dear to him because of the exchange of shared cultures. ${ }^{18}$ Therefore the man appointed to the province of Achaea as proconsul would have been of no small concern to him.

In addition, the use of the designation, 'my friend' $(l .6)$ by the emperor was not simply an official convention in imperial letters. It was a public declaration of his confidence in Gallio in the light of his report on Delphi, which had resulted in Claudius' attempt to revival Delphi as a significant cultic centre that would have included the imperial cult. As Miriam Griffin noted 'when the emperor called someone his friend, it was virtually a title bestowing on its holder high social cachet ... and the expectation of being asked from time to time to advise the Emperor as a member of his consilium.' 19 Claudius cast Gallio in this role in connection with his highly significant plans for Delphi.

In Republican times a consul was the highest elected magistrate. Two were elected annually and they gave their names to the calendar year. Their powers outside of Rome had been largely unrestricted but in Rome were defined or limited by statute or by the delegation of responsibilities to other magistrates. The period he held office as proconsul of Achaia was 1st July, 51 until 30th June, 52.

After his return, he and T. Cutius Ciltus were elected the two suffect consuls of Rome in AD 56 in the stable era of Nero's principate and not as late as AD 58 has been suggested. ${ }^{20}$

It has been suggested that the alleged desertion of his important proconsulship of Achaea could be forgotten soon enough for Gallio to secure this senior office in Rome. Memory was not that short in Rome

17 B. M. Levick, 'Greece (including Crete and Cyprus) and Asia Minor form $43 \mathrm{BC}$ to AD 69', in A. K. Bowman, E. Champlin and A. Lintott, The Augustan Empire, 43 BC$A D$ 69, The Cambridge Ancient History vol. X (Cambridge: Cambridge University, 1996): 654-5.

18 Suetonius, 'The Deified Claudius': 42.

19 Griffin, Nero: 71

20 G. Comedeca, 'I consoli del 55-56 e un nuovo collega di Seneca nel consolato: P. Cornelius Dolabella' ZPE 63 (1986): 208-10 pace Murphy-O'Connor, St Paul's Corinth: 168. 
and mismanagement of provincial affairs could result in criminal litigation by provincials against a former proconsul. Acts 24:26 records that Felix sought a financial consideration from Paul while he was in custody, and such conduct could result in a case being mounted in Rome after following the expiration of a provincial appointment. There is evidence of a successful criminal action brought against the Prefect C. Vibius Maximus, and the outcome was the punishment of damnatio with the obliteration of all offical references to him, as the extant inscriptions in Egypt clearly bear witness. ${ }^{21}$ This did not happen with respect to Gallio's governorship of Achaea ${ }^{22}$. He would not have secured his post in Rome had this been the case.

\section{Gallio's Family Medical Condition}

Gallio's character has been cast in a poor light, alleging that he was a hypochondriac who deserted his post in Corinth during his proconsulship and went on a Mediterranean 'cruise' to recover. ${ }^{23}$

In a discussion titled 'On the Medicinal use of seawater', Pliny the Elder (AD c.23/4-79) recorded 'there being many other uses, the chief however being a sea voyage for those attacked by consumption, as I have said, and for haemoptysis, ${ }^{24}$ such as quite recently within our memory was taken by Annaeus Gallio after his consulship (post consulatum).' ${ }^{25}$ According to Pliny it was after he completed the oneyear term set for a senatorial consulship.

The Latin medical term Pliny used was transliterated from the Greek and means 'I spit blood' (ai $\mu \alpha \pi \tau u ́ \omega)$. In contemporary medical terms it refers to coughing up blood from the respiratory tract. Pliny draws a distinction between the medical condition known as consumption and haemoptysis. ${ }^{26}$ Gallio was suffering from this diagnosed illness and after completing his term as proconsul he took a sea voyage because

21 Syme, 'C. Vibius Maximus, Prefect of Egypt': 484.

22 See A. B. West, Corinth: Latin Inscriptions, VIII.2, no. 1, line 3 as an example in Corinth where Mark Anthony's name was partially erased as an example of official damnation, after he was defeated by Augustus. See the image at www.tyndale.cam.ac. uk/Tyndale/Staff/Winter/Photos/MarkAnthonyDamnatio.jpg.

23 Murphy-O'Connor, St Paul's Corinth: 168

24 D. M. Anderson, Moseby's Medical Dictionary (6th ed.; St Louis: Moseby, 2002): 801.

25 Pliny the Elder, Natural History 33:62.

26 Pliny the Elder, Natural History 31:62. 
he, like Pliny and Celcus - a famous doctor in the reign of Tiberius believed in the therapeutic properties in seawater.

If strength allows of it a long sea voyage is requisite with a change of air, of such kind that a denser climate should be sought than that which the patient quits; hence the most suitable is the voyage to Alexandria from Italy ... Further the patient should be kept away from business. ${ }^{27}$

Not only did Pliny discuss Gallio's medical problem, but Seneca refers to it in a letter: 'I remembered my master [his elder brother], Gallio's words when he began to develop a fever in Achaea and took ship at once, insisting that the disease was not of the body but the place. ${ }^{28} \mathrm{He}$ had begun his post in July in the very humid month in Corinth.

This excerpt is from Seneca's extensive letter 'On Care of Health and Peace of Mind', written after he had been ill in Rome and, on his doctor's advice, left for his villa at Nomentum in spite of his wife Pompeia Paulina's efforts to stop him. ${ }^{29} \mathrm{He}$ blamed his state of health on the environment of Rome.

As soon as I escape from the oppressive atmosphere of the city, and from that awful odour of reeking kitchens which, when in use, pour forth a ruinous mess of steam and soot, I perceived at once that my health was mending. And how much stronger do you think I feel when I reached my vineyards. So I am my old self again, feeling now no wavering languor in my system. ${ }^{30}$

Seneca justified his leaving Rome on the basis that his brother left Corinth 'immediately' in order to recover.

The evidence points to the fact that both brothers suffered from the same medical condition, with Seneca leaving the pollution of Rome and Gallio that of Corinth in summer. Miriam Griffin noted 'He shared with Seneca rather the tendency to consumption.' ${ }^{31}$ Pliny reported that it was after the consulship that he went on a sea voyage to recover. Given that the tenure of his post in Corinth began with the summer and ended with the next, there need not be a conflict in the evidence. If there is, then Seneca's evidence carries more weight because he had more intimate knowledge of his older brother's movements. However, neither he nor Pliny suggested that he deserted this senior posting

27 Celcus, de Medicina, Book 3.22.3-14 esp. 8-9.

28 Seneca the Younger, Letters: 104.1.

29 Seneca the Younger, Letters: 104.2.

30 Seneca the Younger, Letters: 104.6.

31 Griffin: Seneca: A Philosopher in Politics: 47. 
during the period of his proconsulship never to return. The description of Gallio as 'a fussy hypochondriac' seems to be somewhat unfair in the light of what is known from our sources about the medical problem of both brothers.

\section{Gallio's Known Aversion to Flattery}

Seneca the Younger comments at length on Gallio's character in his preface to Natural Questions, written to his close younger friend Lucilius (who by this time was proconsul of Sicily). He addressed a good deal of his extant writing to him, using a very personalised form of address: 'My dear Junior.'

Corcoran noted in his translation of Sections 10-12 that 'Seneca treats Lucilius the Younger's attempts to flatter Gallio, and the results, as past fact.' He then provides an explicit reason for not doing so in his rendering of the text. 'In English it sounds better when treated as hypothetical.' ${ }^{32}$ Assonance however does not constitute a justifiable argument for dealing with the passage as if it were not discussing an interaction that had occurred between Lucilius and Gallio.

\section{Senaca writes of Gallio:}

I used to tell you that my brother Gallio who is not loved as much as he deserves even by those whose love for him could not be greater does not know other vices, hates flattery. You tested him on every side. You looked up to his intelligence as the greatest of all and very deserving of his preference that it be ranked among the gods instead of being malignantly crushed. He dodged the trip-up. You begun to praise his frugality, that so recoiled from our manners that it seemed neither to possess nor condemn them. He immediately cuts short the first words [of flattery]. You admired his ability to get along with other people and his unaffectedly pleasing personality that charmed even those it paid no special attention to, [was] a free benefit even for those who meet him. No other human being is so charming to just one person as he is to all people. As the same time the power of his natural goodness is so great that it has no odour of artifice or dissimulation. No human being would refuse him being credited with a goodness that applied to the entire community. At this point he resisted your flattery; so you might exclaim you have found a man impervious to deceptions that anyone else accepted wholeheartedly. You have confessed that you admire all the more this common sense of his and persistence in avoiding an inevitable

32 T. H. Corcoran, Seneca the Younger, Naturales Quaestones II., Loeb Classical Library (Cambridge, Mass., and London: Harvard University e.g. and Heinemann, 1972): 9 , n. 3. 
evil, because you expressed the hope that however much alluring flattery you spoke, it was accepted with open ears because you were speaking the truth. Yet he realised all the more that you had to be resisted; for, when falsehood was presumably involved, the authority of truth was sought for by a true man. Yet, none the less I dio not want you to be displeased with yourself, as though you acted your role poorly and Gallio suspected some joke or trick. He unmasked you but did not reject you. ${ }^{33}$

Seneca then concludes that this was an imperative:

model yourself after this pattern. When any flatterer approaches you, say: "Those words of yours are the formal compliments that pass from one magistrate to another along with the lectors. Will you be pleased to take them to someone who, ready to render like for like, is willing to listen to anything you say? As for me, I am neither willing to be deceived nor can I be deceived." 34

Here, he is recalling the interaction that had occurred between Gallio and Lucilius. The latter's knowledge of the former is being rehearsed by Seneca to this close friend of his. It was not a hypothetical situation, as Corcoran rendered the passage.

There certainly was a close friendship between Seneca and Lucilius: 'I prefer my letters [to you] would be as if you and I were sitting in one another's company or taking walks together - spontaneous and easy;' they communicated by letter because the latter was then in Sicily. Gallio and Lucilius were well acquainted, to the point of a frank criticism made by the former about the latter's casual letter-writing style. ${ }^{35}$

Seneca's discussion was not a flattering, overdrawn portrayal of his brother's virtues, but one that Lucilius could verify from his own interactions with Gallio. Furthermore, he was not discussing his brother's character with Lucilius for the first time, as he himself noted in the same letter, 'I used to tell you that my brother, Gallio...'36

Miriam Griffin, who takes seriously this profile, concludes that Gallio 'was of a gentle disposition with a distaste for flattery'. ${ }^{37}$ There emerges from Seneca's profile an older brother who possessed integrity. While Nero was said to have commented soon after his accession that 'Claudius by means of a mushroom has become a god' - a refer-

33 Preface, Natural Questions, IVA: 10-12.

34 Preface, Natural Questions: 13

35 See Seneca, 'On the diseases of the soul,' Letter to Lucilius: 1xxv. See also M. Griffin, Seneca: A Philosopher in Politics (Oxford: Oxford University, 1992).

36 Seneca, the Younger, Natural Questions IVA, Pref. 10.

37 Griffin, Seneca: A Philosopher in Politics: 47. 
ence to his possibly being poisoned by Agrippina - Gallio remarked 'that Claudius had been raised to heaven with a hook' - the means used to drag executed prisoners to the Forum before being hauled to the river. ${ }^{38}$ In Gallio's coded language, Nero had been acting in a criminal way before his death. Gallio was his own person, and his integrity had been developed through his upbringing with his famous father in Rome, and then continued with his adopted father, an eminent rhetorician and Roman senator.

\section{Gallio's Courtroom Protocol}

Gallio's brother was convinced of his sibling's integrity, his respect for others and his intellectual prowess, which expressed itself with the reputation he acquired as a Roman jurist. In the light of this, Luke's report of the judgement of Gallio and the way he conducted the preliminary hearing with judicial correctness seems to reflect what we learn from Seneca's profile of his brother.

Seneca reminded Lucilius that his brother was not inept in his relationships with others. He had a great 'ability to get along with other people and his unaffectedly pleasant personality charms even those it pays no attention to ... No other human being is so charming to just one person as he is to all people.' In Corinth, Gallio politely addressed them as 'O Jews', and explained that he simply could not proceed because there was no case to answer under Roman law. Luke records that he added, 'If it were a matter of wrong-doing or vicious crime, then I would have reason to allow the legal proceedings' $(18: 14) .{ }^{39}$

Nevertheless, Gallio had refused to collude with the Jews in the way that Pontus Pilate had and Felix would. Pilate had succumbed to the pressure of having to show, in the case of the Jews versus Jesus, that he really was 'Caesar's friend' (John 19:12). Felix secured his governorship of Judea at the special request of Ananias, the High Priest, who was present at the trial. Felix was not strictly eligible for this appoint-

38 Dio Cassius, 60:35:4, 60:34:2.

39 'Avєхона $1=$ I would accept the legal grounds and allow the case to proceed. And

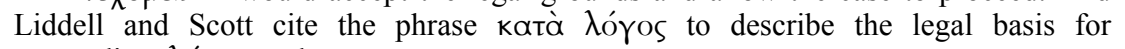

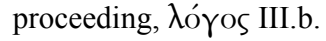


ment given his rank, so he 'owed' the High Priest (Acts 24:1). ${ }^{40}$ Gallio, even though he was 'Caesar's friend', would not proceed with this case because the arguments on which he was petitioned did not breach Roman law.

Of Gallio, Seneca wrote to Lucilius that 'he realized all the more that you [Lucilius] must be resisted.' He then reminds the procurator of Sicily how vulnerable he is to flattery in his present post and how his brother rejected Lucilius because of it. Seneca explains 'for, when falsehood is presumably involved, the authority of truth is always sought for by a true man.' He concluded that Gallio was an astute judge of character, and had suspected 'some joke or trick', but was not the sort of person who publicly unmasked such persons and thereby caused them to feel shame, something dreaded by Roman citizens ${ }^{41}$ He puts it succinctly 'He would not unmask you, but he would reject you' (non deprehendit te sed reppulit). It is being suggested that this is reflected in Luke's report that he handled the Jews during the actual proceedings by unmasking the plaintiffs but in this case rejecting them as the law required in any criminal action if there was no case to answer.

The impression gained from Seneca is that Gallio was an astute judge of situations, and would have been aware of the hubris and the troubling nature of the litigation that had driven the Jews to pursue this case, and the duplicity that stood behind their charges. In fact Luke

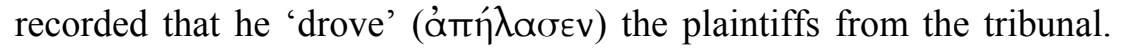
What is to be made of this comment? It does square with the reference by Seneca the Younger to Gallio's rejection of attempts to manipulate him - 'He would reject you.' The Jews versus Paul was a case of what Gallio perceived to be a vexatious matter.

What is to be made of Luke's assessment that 'and none of these

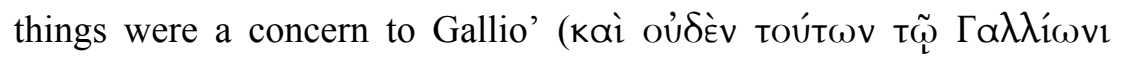
ع $\mu \varepsilon \lambda \varepsilon v)$ 18:17? And to what does the plural genitive demonstrative

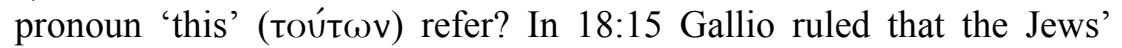
dispute with Paul was related to words and names and their own law, and as a result 'I myself am not minded or willing to be a judge with respect to these (Toút $\omega \mathrm{v}$ )'. The referents of the demonstrative pronoun

\footnotetext{
40 See my article, 'The Role of the captatio benevolentia in the Speeches of Tertullus and Paul in Acts 24', Journal of Theological Studies, n.s. 42.2 (November, 1991): 5156 .

41 Seneca, Natural Questions IVA, Pref. 10.
} 


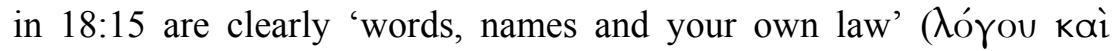

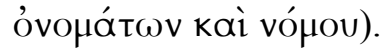

What would have been a concern to Gallio had already been

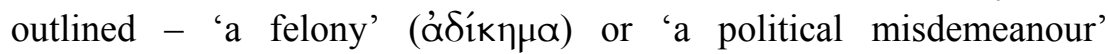

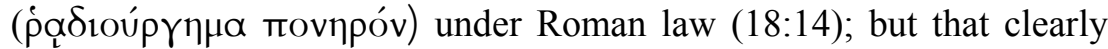
was not the case in this proposed prosecution.

It is normally assumed that the referents of the plural demonstrative pronoun in 18:17 are the actions of the 'seizing' and 'beating' of Sosthenes. However it could be argued that this demonstrative pronoun refers to the issues raised by the Jews in their legal petition because they could not stand up in court. If this is the case, then Luke ends the narrative by underscoring the importance of the refusal of Gallio to proceed because the Jews had no legal case to bring against the Christians under Roman law.

What was the reason for this fracas in the Corinthian forum? There are a number of possibilities. It is known that leading Roman citizens followed by their clients attended in the forum, and they operated as loyal supporters of their patrons in the realm of politeia. Those standing around saw the dismissal of Jews' case in the Roman criminal court as an opportunity to demonstrate their support for the emperor's recent anti-Jewish decree recorded by Luke in Acts 18:2 - 'because Claudius had commanded all Jews to depart from Rome' - hence their beating the new leader of the synagogue. Would this better resonate with the role of clients who would gather with their patrons around the tribunal, and the general expectation that good citizens of Roman colonies demonstrated their loyalty to the emperor's policies? Roman colonies were clones of Rome.

Another suggestion is that this response was a typical of urban uprisings in the Roman world. Evidence for this has been canvassed by Hubbard from ancient sources in order to show that "no special hypothesis if racial animosity is needed to account for this sudden eruption'. ${ }^{42}$ The following scenario has been suggested:

A plausible historical reconstruction of the critical moments beneath the tribunal is not difficult to imagine. Following Gallio's abrupt dismissal of the suit against Paul, lectors move in, rods in hand, and begin to forcibly eject the (already agitated) plaintiffs, forcusing on the leader of the throng, Sosthenes. Tempers flare so Sosthenes is bullied from the

42 M. V. Hubbard, 'Urban Uprisings in the Roman World: the Social Setting of the Mobbing of Sosthenes' New Testament Studies 51 (2005): 426. 
front and pulled from behind; undoubtedly he pushes back, in both directions. The market layabuts join the kerfuffle, which quickly degenerates into fisticuffs, with Sosthenes now getting it from both sides, Gallio hardly notices; he has already moved on to other business. ${ }^{43}$

Yet Hubbard in his conclusion concedes 'Having said this (i.e. 'urban rest is the primary lens though which we should evaluate the mobbing of Sosthenes in Acts 18:12-17'), it is reasonable to assume that xenophobic and, more specifically, judaeophobic sentiments would have been present among at least some of the onlookers who (likely) participated in the commotion.'

There are difficulties with this recent proposal. Roman governors had to intervene in such cases as part of their imperium, and had to treat such cases of civil unrest and public violence seriously. ${ }^{44}$

Furthermore, Luke later recorded the declaration of the city clerk that if the city-wide civil disturbance in Ephesus that resulted in an illegal gathering in the theatre came to the ears of the governor, then he would certainly intervene and penalise them. He exhorts them as to the due process: 'the courts are open and there are proconsults, let them accuse one another there.' (19:38).

E. A. Judge commented:

It has always been a puzzle how so meticulous a lawyer as Gallio could have regarded an assault of this kind with such apparent equanimity. It cannot admittedly be said that Sosthenes was in any way legally penalized. After all, he had not lost his suit; it had merely been disallowed. But the suspicion that accrued to unsuccessful litigation may have created the atmosphere in which an outrage of the present kind could be ignored. ${ }^{45}$

He preceded these comments with a suggestion as to the wider consequence for Christian of the ruling in Corinth, suggesting 'the possibility of an intensified campaign of slander with a view to prejudicing the courts was opened up'. ${ }^{46}$

Paul's later experience recorded in Philippians 1:16-17 provides a possible example of the pre-trial rumour-mongering and blatant moves to prejudice the actual outcome of the proceedings by creating trouble

43 Hubbard, 'Urban Uprisings': 427.

44 R. Taubenschlag, The Law in Greco-Roman Egypt in the Light of the Paypri (Milan: Ristampa Anastatica, 1972): 43.

45 E. A. Judge, The Social Pattern of Christian Groups in the First Century (London: Tyndale, 1960): 69.

46 Judge, The Social Pattern of Christian Groups: 68. 
for Paul, who was in custody awaiting trial. ${ }^{47}$ This sort of activity and the intention was well known. ${ }^{48}$ The technical term 'discredit' ( $\delta 1 \alpha \beta o \lambda \eta ́)$ was used of it and $\varphi \theta$ óvos (Phil. 1:15) indicated that an opponent "not only dislikes ... but wishes actively to see him harmed' ${ }^{49}$ While the Jews wished to harm Paul - 'with one accord they rose up against Paul and brought him to the judgement seat' (18:13) - the Roman patrons and clients present in the forum turned the tables against Sosthenes. It is suggested that it was not a case of any indifference on the part of Gallio to an 'urban uprising'.

It is more likely that Luke's final comment is to be interpreted as referring to how Gallio had operated in this case. He drove the accusers from the judgement seat because their case was groundless in Roman law, carefully following the correct legal protocol within whose parametres he alone operated. He was rightly not concerned with matters outside the formal court hearing, for what happened was not within his remit unless Sosthenes subsequently brought another private prosecution, for assault. As Luke rightly noted 'and none of these things $(18: 15,17)$ concerned Gallio', but had Paul been guilty of those in 18:14 he would certainly have proceeded with the case.

\section{Gallio's Legal Arguments ${ }^{50}$}

Luke records the proconsul's legal ruling that the disputes in this case revolved around three issues: 'about words and names and your own

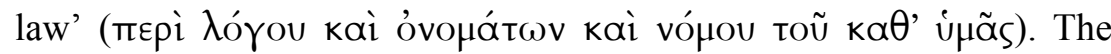
term $\lambda$ óros used to refer to 'a declaration of legal immunity'. ${ }^{51}$ Jews possessed this in relation to the observation of the imperial cult, and offered sacrifices for the emperor in a temple in Jerusalem but not to

47 For the imperial era and a discussion in Philippians 1:27-2:18 see my Seek the Welfare of the City: Early Christians as Benefactors and Citizens (Grand Rapids and Carlisle: Eerdmans and Paternoster, 1994): 81-104.

48 For an excellent discussion of evidence from the Republican period see D. F. Epstein, 'Inimicitiae and the Courts', Personal Enmity and Roman Politics 218-243 $B C$ (London: Routledge, 1987): ch. 5.

49 K. M. D. Dunbabin and M. W. Kickie, 'Invidia rumpantur pactora: Iconography of Phthonos/Invidia in Graeco-Roman Art', JbAC (1983): 7-37, cit. 10.

50 This section is a summary of a fuller discussion in 'Gallio's ruling on the legal status of early Christianity (Acts 18:14-15)', TynBul. 50.2 (Nov. 1999): 218-22.

51 See this additional classification of $\lambda$ ó $\gamma$ os in the Revised Supplement to Liddell and Scott (1996): VII.6 citing Justinian, Nov. 17.6, Edict 2 pr. 
him. ${ }^{52}$ A cogent argument in confirmatio of the petition could have been that Paul had gone on record as having disassociated himself from the synagogue - 'from henceforth I will go to the Gentiles' (18:6) and therefore could no longer operate under the aegis of the legal status of the Jews.

The second reason for not being able to proceed concerned 'names'

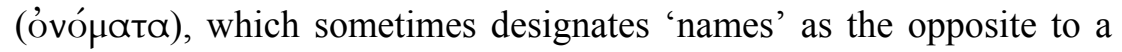
real person and can refer to 'false names' or 'pretexts' or 'terms'. 'Roman law held a person liable for actions and not for any name they professed.' 53 Gallio enunciated this important principle that would have precluded proceeding on the basis of 'names' in a criminal action.

Gallio referred specifically to 'the law, your own' (vó $\mu$ ou тoũ ka $\theta$ ' ن $\mu \tilde{\alpha} \varsigma)$. In declaring that it was an issue concerning 'the law, your own', he is drawing a sharp contrast between Jewish law and Roman law. Breaches of the latter, the Jews alleged, constituted the grounds of Paul's guilt. In giving this judgement, he clearly rejected the charge Paul had in any way breached Roman law.

The legal ruling that is succinctly summarised in Acts 18:14-15 made it clear that Paul was not guilty of 'a felony' or 'a political misdemeanour' under Roman criminal law (18:14).

Gallio then proceeds to assure the plaintiffs that if their charge could be sustained, he would naturally proceed with the case, for he would be justified in accepting their charge. The words 'to be justified'

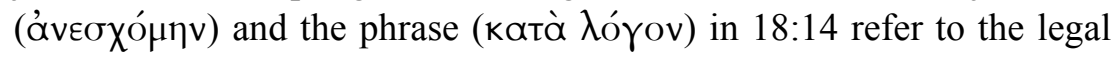
grounds for a charge. ${ }^{54} \mathrm{He}$ gives his considered judgement, stating that the issue before him related to 'subjects of dispute' or 'claims'

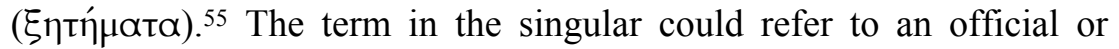
judicial enquiry or 'claim'. Festus would also use it concerning the case of the Jews versus Paul in another Roman province - 'Jews had certain

52 M. H. Williams, The Jews among the Greeks and Romans (London: Duckworth, 1998): 91; W. Cotter, 'The Collegia and Roman Law: State restrictions on voluntary associations' in Stephen G. Wilson and John S. Kloppenborg, eds, Voluntary Associations in the Graeco-Roman World (London: Routledge, 1996): 82; O. F. Robinson, The Criminal Law of Ancient Rome (Baltimore: Johns Hopkins, 1996): 17.

53 This is very different from the second century when Christians were put to death on the grounds of 'the name', i.e. 'Christian'. See S. Benko, 'The Name and its Implications' Pagan Rome and the Early Christians (London: Batsford, 1984): ch. 1

54 For the use of this phrase to describe the legal basis for proceeding, see Liddell and

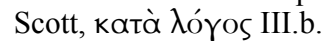

55 For the meaning 'official or judicial enquiry' see P.Oxy. 97.14; and 'claims' P.Ryl. 117.14 (AD II) and $S I G 785$ (AD I). 
claims against him of their own superstition' ( $\delta \varepsilon 1 \sigma 1 \delta \alpha \iota \mu$ ovía) (Acts 25:19).

\section{Conclusions}

What can be concluded in light of the above examination of the extant witnesses? Seneca's testimony where he reminded Lucilius of what Gallio knew about him is important both in terms of what we know of Seneca, and also in that it has some resonances with Luke's summary of the preliminary proceedings.

You [Lucilius] looked up to his intelligence ... He immediately cuts short the first words [of flattery] ... At this point he resisted your flattery; so you might exclaim you have found a man impervious to deceptions that anyone else accepted ... [and] when falsehood was presumably involved, the authority of truth was sought for by a true $\operatorname{man}{ }^{56}$

Luke's succinct courtroom profile resonates with this.

Governors were normally accompanied by a set of legal advisors, who would assist them in resolving criminal cases in accordance with Roman law. ${ }^{57}$ Luke's account that Gallio did not call for the customary recess at the preliminary hearing that was typical of such proceedings, but gave his immediate judgement on the legal merits of their petition, may be a reflection of his legal competence, and was somewhat unexpected, as he delivered his ruling as Paul was about to make the expected defence (18:14). Ancient witnesses confirm Judge's succinct comment that Gallio was 'meticulous' as a lawyer, to which might be added the comment that he was a highly competent one.

Based on the accounts of the extant witnesses it is suggested that Gallio deserves to be rehabilitated and no longer relegated to an incidential role in New Testament chronology based on the Olympian imperial inscription. ${ }^{58}$ It is suggested too that an extremely important corollary is that due weight be given to the first judgement made at a

56 Preface, Natural Questions, IVA, 10-12.

57 See D. Braund, 'Cohors, The Governor and his entourage in the self-image of the Roman Republic' in R. Laurence and J. Berry, ed., Cultural Identity in the Roman Empire (London: Routledge, 1998): ch. 2.

58 My point of departure with J. Murphy-O'Conner on the assessment of Gallio should not detract in any way from my appreciation of his important service to New Testament Corinthian studies with what is now the third edition of his excellent collection of primary literary sources and some of the important inscriptions. 
provincial Roman criminal hearing on the status of the first Christians. $^{59}$

59 'Official Proceedings and Forensic Speeches in Acts 24-26', in A. D. Clarke and B. W. Winter, ed., The Book of Acts in its Ancient Literary Setting (Grand Rapids: Eerdmans): ch. 11. 